\title{
EFFECTS OF CHITOSAN AND SALICYLIC ACID ON PHYSIOLOGICAL CHARACTERISTICS OF EGGPLANT (Solanum melongena)
}

\author{
Hossaini $\mathrm{SE}^{1}$, Nakasha $\mathrm{JJ}^{* 1}$, Zaharah $\mathrm{SS}^{1}$ and Faezah $\mathrm{NO}^{2}$ \\ ${ }^{I}$ Department of Crop science, Faculty of Agriculture, Universiti Putra Malaysia, 43400, \\ Serdang, Selangor, Malaysia \\ ${ }^{2}$ Faculty of Plantation and Agro technology, Universiti Teknologi MARA (Perlis), 02600, \\ Arau, Malaysia
}

\begin{abstract}
Eggplant (Solanum melongena) falls under the fruit species under the family of Solanaceae. It is grown widely throughout tropical and subtropical Zones in the world. It is a good source of phenolics, flavonoids, vitamins, calcium and protein. Due to its high nutritional properties, the demand for eggplant is increasing annually. However, due to limited planting space, it is difficult for the producers to increase the production in order to meet the demand. Thus, the objective of this study is to improve the growth and development of selected physiological characteristics of eggplant with chitosan and salicylic acid. The experiment was carried out in factorial randomized complete block design (RCBD) with 4 replications. This experiment was conducted at Field 15, Universiti Putra Malaysia. The plants were treated with chitosan and salicylic acid at four different rates; 0, 2, 4 and 6 $\mathrm{ml} / \mathrm{L}$ for chitosan and 0,50,100 and $150 \mathrm{mg} / \mathrm{L}$ for salicylic acid. The treatments were applied either alone or in combination. Results revealed that the application of chitosan combined with salicylic acid influenced the physiological characteristics of the eggplant compared to the control group. Combination of $4 \mathrm{ml} / \mathrm{L}$ chitosan with $150 \mathrm{mg} / \mathrm{L}$ salicylic acid gave the highest mean values of plant height $(107.13 \mathrm{~cm})$, number of branches (14.91), number of leaves (136.08), total number of flowers per plant (101.8), compared to other treatments. Therefore, due to cost effectiveness and better impact on physiological characteristics the combination of $4 \mathrm{ml} / \mathrm{L}$ chitosan and $150 \mathrm{mg} / \mathrm{L}$ salicylic acid as foliar fertilizer is recommended to improve the growth and development of eggplant.
\end{abstract}

Keywords: Solanum melongena, chitosan, salicylic acid, physiology

\section{Introduction}

Eggplant (Solanum melongena L.) or also known as garden egg or brinjal, is an important warm weather crop, mainly grown in the tropical and subtropical regions of the world. It is native to India, with China and Japan known as secondary canters of its origin (Gisbert et al., 2016; Mariano-Nasser et al., 2019; Page et al., 2019; Ullio, 2003). About 54 million tons of eggplants were produced in 2018, with $93.7 \%$ in Asia, $3.8 \%$ in Africa, $1.8 \%$ in Europe and $0.7 \%$ in America (FAO, 2018). China is the largest producer of eggplant, followed by India and Egypt (FAO, 2018). The rapid increase in the world population has intensified the demand for food and decreased accessible planting space resources. Eggplant is rich source of vitamins, minerals, protein and fibre. Eggplant contains various phytochemicals such as flavonoids which are really helpful for medicinal purposes (Basudan, 2018). Thus, it is identified as one of the healthiest and beneficial fruit for human health (Docimo et al., 2016; Plazas et al., 2014; Raigón et al., 2008). One of the major obstacles faced in eggplant production is the lack of planting area to expand the production. It is difficult to increase the production without increasing the planting area. Furthermore, the global climate changes also limit the production of eggplant. As an alternative to counter these difficulties, the application of chitosan and salicylic acid on eggplant might be a good option.

Chitosan is deacetylated from chitin, which acts as a potent bio stimulant and an elicitor in plant systems (Xu and Mou, 2018). Due to its properties of biocompatibility, eco-friendly and easily available in large quantities, chitosan offers a sustainable agriculture practice (Xu and Mou, 2018). Due to its cationic character, chitosan influences

*Corresponding author email: jujunakasha@upm.edu.my

C) TIIKM Publishing 
various biological and physicochemical properties, including antimicrobial, antifungal and antioxidant (Aranaz et al., 2009; Xu and Mou, 2018). Chitosan has been used in agriculture sector with the aimed to increase the yield. Akter et al. (2018) has proven that chitosan helps in increased in yield for chilli planted under Bangladesh climate. The same pattern was also found in chilli planted in Indonesia, as reported by Aziz et al. (2020). Besides, Esyanti et al. (2019) found that chitosan significantly increased the vegetative growth of chilli pepper in Indonesia. Moreover, spraying chitosan on summer squash has significantly increased plant growth characteristics, yield and its components (Ibraheim and Mohsen, 2015).

Salicylic acid is a plant phenolic compound, phytohormone or natural plant growth regulator and signalling molecule. It is biosynthesized from the two independent pathways, isochorismate synthase- and phenylalanine ammonia-lyase (PAL) dependent pathways (Dempsey and Klessig, 2017) that affects various processes in plant systems metabolically and physiologically (Jayakannan et al., 2015; Vicente and Plasencia, 2011). Salicylic acid also influences the flower induction, transpiration, ion uptake, enhancement of chlorophyll level and photosynthesis rate (Amanullah et al., 2010; Sahu, 2013; Souri and Tohidloo, 2019). Besides, it is also able to protect the plants under stressful conditions where summer squash showed an increased in yield under salinestress condition in Egypt (El-Mageed et al., 2016). Additionally, application of salicylic acid positively and significantly altered the growth and yield in cucumber under different irrigation levels in Egypt (Nada and ElHady, 2019). Growth regulatory effects of salicylic acid in growth and yield improvement may be associated to its potential in reducing stress related growth inhibition in plants (Khan et al., 2015). Thus, the objective of this experiment is to assess the impacts of chitosan and salicylic acid in improving plant growth and development in eggplant.

\section{Material and Methods}

The experiment was carried out at Field 15, Universiti Putra Malaysia under greenhouse condition. The eggplant seeds were sown in germination tray containing peat moss and placed under $50 \%$ shade for the seeds to germinate. Healthy and uniform seedlings with four leaves per seedling were transplanted into 16"x16" poly bags containing coco peat. As the plants reached 20 days after transplanting (DAT), the plants were sprayed with chitosan and salicylic acid at four different rates; 0, 2, 4 and $6 \mathrm{ml} / \mathrm{L}$ for chitosan and 0, 50, 100 and $150 \mathrm{mg} / \mathrm{L}$ for salicylic acid. The treatments were applied either alone or in combination. The experiment was designed in factorial randomized complete block design (RCBD) with four replications.

\section{Data collection}

Data were collected on 110 DAT for the following parameters:

a- Number of leaves per plant: measured by counting all the leaves existed in each plant.

b- Plant height: measured manually by using a measuring tape. Plant height was taken from the medium surface to the highest point of plant stem and result was expressed in centimeter $(\mathrm{cm})$.

c- Number of branches per plant: measured by counting all branches from the main stem.

d- Total number of flowers per plant: was counted from 57 DAT until 110 DAT by counting flowers that were anthesis only. 


\section{Hossaini et al.}

\section{Statistical analysis}

Data were subjected to statistical analysis and were analyzed using Statistical Analysis System (SAS 9.4). Means were analyzed using Analysis of Variance (ANOVA) and compared using Least Significant Differences (LSD) at significant level of 0.05 .

\section{Results and Discussion}

\section{Number of leaves}

Outcome of this study obviously showed that foliar application of chitosan and salicylic acid alone or in combination exhibited positive impacts on number of leaves per plant in eggplants. Based on the result in Table 1 , increasing the concentration of chitosan $(\mathrm{CH})$ and salicylic acid $(\mathrm{SA})$ resulted in significant $(\mathrm{P} \leq 0.05)$ increase in the number of leaves per plant. The highest number of leaves was observed on plants that were treated with combination of $4 \mathrm{ml} / \mathrm{L} \mathrm{CH}+150 \mathrm{mg} / \mathrm{L}$ salicylic acid which was 136 leaves per plant. It was followed by the application of $2 \mathrm{ml} / \mathrm{L} \mathrm{CH}+150 \mathrm{mg} / \mathrm{L} \mathrm{SA}$ (133 leaves per plant) and $4 \mathrm{ml} / \mathrm{L} \mathrm{CH}+100 \mathrm{mg} / \mathrm{L} \mathrm{SA}$ (130 leaves per plant), with no significant difference between these two treatments. On the other hand, there was a non-significant increase in number of leaves (102, 102, 102 and 106 leaves per plant) by application of 2 and $4 \mathrm{ml} / \mathrm{L} \mathrm{CH}$ and 50 $\mathrm{mg} / \mathrm{L}$ SA when applied individually compared to the control group and by application of $2 \mathrm{ml} / \mathrm{L} \mathrm{CH}+50 \mathrm{mg} / \mathrm{L}$ $\mathrm{SA}$ respectively. Low concentration of $\mathrm{CH}$ and SA failed to influence the number of leaves in eggplants, where it showed non-significant difference when compared to the control group. Besides, the effects were not profound without the combination of chitosan and salicylic acid.

Table 1: Impact of different levels of chitosan and salicylic acid on number of leaves plant ${ }^{-1}$

\begin{tabular}{|c|c|c|c|c|c|}
\hline \multirow[b]{3}{*}{ Chitosan, $\mathrm{CH}$ (ml/L) } & \multicolumn{4}{|c|}{ Number of leaves plant ${ }^{-1}$} & \multirow[b]{3}{*}{ Means } \\
\hline & \multirow[b]{2}{*}{0} & \multicolumn{2}{|c|}{ Salicylic acid, SA (mg/L) } & \multirow[b]{2}{*}{150} & \\
\hline & & 50 & 100 & & \\
\hline 0 & $101.25 \mathrm{f}$ & $102.66 \mathrm{ef}$ & $105.83 \mathrm{ef}$ & $112.25 \mathrm{~d}$ & $105.5 \mathrm{C}$ \\
\hline 2 & $102.16 f$ & $106 \mathrm{ef}$ & $113.66 \mathrm{~cd}$ & $133.41 \mathrm{ab}$ & 113.8B \\
\hline 4 & $102.33 \mathrm{f}$ & $113.33 d$ & $130.91 b$ & $136.08 \mathrm{a}$ & $120.66 \mathrm{~A}$ \\
\hline 6 & $111.5 \mathrm{de}$ & $113.83 \mathrm{dc}$ & $117.58 \mathrm{bcd}$ & $119.83 c$ & $115.68 \mathrm{~B}$ \\
\hline Means & 104.31D & $108.95 \mathrm{C}$ & $114.5 \mathrm{~B}$ & $125.39 \mathrm{~A}$ & \\
\hline
\end{tabular}

Means with different letterings are considerably different in same column and row at $p \leq 0.05$ LSD. Upper and lower cases are demonstrating analysis by factorial and single factor respectively.

Leaves are important organ of plants where photosynthesis occurs; an occurrence which leads to the plant growth and manufactures food for plants and other organisms (Ashraf and Harris, 2013). The increment in number of leaves is in consistency with the result of Mohamed et al. (2017) who reported that salicylic acid has significantly increased the number of leaves per plant in strawberries, Abbasi et al. (2019) in cucumber and El-Yazied (2011) in sweet pepper. Regulatory potential of SA in increasing the number of leaves may be linked to its influences on the chlorophyll level, stomatal movement and enzymes, which contribute in photosynthesis activities in plants (Vicente and Plasencia 2011). Besides, it might be also due to efficiency of nutrient uptake in plants by salicylic 
acid especially, potassium element (Youssef et al., 2017). Potassium plays a key role in plant physiological processes including: stomatal regulation, transport of soluble organic compounds through phloem, balance of cation and anion, photosynthesis, cell growth, manufacturing of protein, osmoregulation, energy transfer, activation of enzymes, induction of stress resistance and nutrient stability (Hasanuzzaman et al., 2018; Pandey, 2015). Besides, it may be also due to impacts of chitosan on other hormones such as cytokinins. Cytokinins increase the number of branches by increasing the lateral buds in plants and contribute in leave production (Qiu et al., 2019).

\section{Plant height}

Plant height is one of the key measurable and observable growth traits in plants. Based on the result, the exogenous application of $\mathrm{CH}$ and SA either independently or in combination, showed significant influence on plant height of eggplant (Table 2). It was also noticed that the effect was less pronounced when $\mathrm{CH}$ was applied without the combination of SA, where 2 and $4 \mathrm{ml} / \mathrm{L} \mathrm{CH}$ showed non-significant effect on plant height with untreated plants, which was around 85.17 until $86.8 \mathrm{~cm}$. A slight difference was found for plants treated with $6 \mathrm{ml} / \mathrm{L}(89.9 \mathrm{~cm})$. Similar pattern was observed in SA, where single application of SA was not effective in increasing the plant height except for $150 \mathrm{mg} / \mathrm{L}$ where the plants reached $90.02 \mathrm{~cm}$ in height. The highest plant height observed in plants which were treated with $4 \mathrm{ml} / \mathrm{L} \mathrm{CH}+150 \mathrm{mg} / \mathrm{L} \mathrm{SA}$ and resulted $20.5 \%$ increment in plant height over untreated plants.

Table 2: Effects of chitosan and salicylic acid on plant height

\begin{tabular}{|c|c|c|c|c|c|}
\hline \multirow[b]{3}{*}{ Chitosan, CH (ml/L) } & \multicolumn{4}{|c|}{ Plant height $(\mathrm{cm})$} & \multirow[b]{3}{*}{ Means } \\
\hline & \multicolumn{4}{|c|}{ Salicylic acid, SA (mg/L) } & \\
\hline & 0 & 50 & 100 & 150 & \\
\hline 0 & $85.17 \mathrm{i}$ & $85.97 \mathrm{ghi}$ & $87.56 f g h i$ & 90.02efgh & $87.18 \mathrm{C}$ \\
\hline 2 & 85.56hi & 88.87efghi & 91.99def & $98.09 \mathrm{~b}$ & 91.13B \\
\hline 4 & $86.79 \mathrm{ghi}$ & $90.26 \mathrm{efg}$ & $96.83 b c$ & $107.13 \mathrm{a}$ & $95.25 \mathrm{~A}$ \\
\hline 6 & 89.9efgh & $92.55 \mathrm{cde}$ & $95.06 \mathrm{bcd}$ & $93.47 \mathrm{bcde}$ & $92.75 \mathrm{~B}$ \\
\hline Means & $86.85 \mathrm{D}$ & $89.41 \mathrm{C}$ & $92.86 \mathrm{~B}$ & $97.18 \mathrm{~A}$ & \\
\hline
\end{tabular}

Means with different letterings are considerably different in same column and row at $\mathrm{p} \leq 0.05$ LSD. Upper and lower cases are demonstrating analysis by factorial and single factor respectively.

El-Amerany et al. (2020) reported that application of chitosan significantly altered the plant height in tomato and in strawberry (El-Miniawy et al., 2013). The growth regulatory impacts of chitosan in increasing the plant length may be linked to a raise in activity of the key enzymes of nitrogen metabolism such as glutamine synthase, protease and nitrate reductase and nitrogen transmit and photosynthesis increment in the leaves which improved the plant growth and development in okra (Mondal et al., 2012). Another report showed that application of SA significantly increased plant height and all vegetative growth in strawberries (Metwally et al., 2013). Regulatory effects of salicylic acid are closely associated to its potential in inducing some physiological processes, such as increasing vegetative growth, photosynthetic pigment and ion uptake, regulating endogenous Phytohormones. El-Yazeid (2011) mentioned that SA increases the level of endogenous auxin and cytokinins in sweet pepper.

\section{Number of branches per plant}

Different levels of chitosan and salicylic acid individually or in combination resulted in statistically significant increase in number of branches in eggplant (Table 3). The highest number of branches per plant was observed 


\section{Hossaini et al.}

from the application of $4 \mathrm{ml} / \mathrm{L} \mathrm{CH}+150 \mathrm{mg} / \mathrm{L}$ SA which was 15 branches per plant. Under $150 \mathrm{mg} / \mathrm{L} \mathrm{SA}$, the plants produced 13 branches per plant when applied with $2 \mathrm{ml} / \mathrm{L} \mathrm{CH}$, which gave similar effect when applied with $6 \mathrm{ml} / \mathrm{L}$ where the plants produced 14 branches per plant. The untreated plants only showed 10 branches per plant, which was statistically non-significant with single application of $2 \mathrm{ml} / \mathrm{L} \mathrm{CH}$ and $50 \mathrm{mg} / \mathrm{L} \mathrm{SA}$.

Table 3: Impacts of chitosan and salicylic acid on number of branches plant ${ }^{-1}$

\begin{tabular}{clllll}
\hline & \multicolumn{5}{c}{ Number of branches plant ${ }^{-1}$} \\
\cline { 2 - 5 } & \multicolumn{5}{c}{ Salicylic acid, SA (mg/L) } \\
\cline { 2 - 5 } Chitosan, $\mathrm{CH}(\mathrm{ml} / \mathrm{L})$ & 0 & 50 & 100 & 150 & Means \\
\hline 0 & $10 \mathrm{j}$ & $10.58 \mathrm{ij}$ & $12.58 \mathrm{def}$ & $12.66 \mathrm{def}$ & $11.45 \mathrm{C}$ \\
2 & $10.5 \mathrm{j}$ & $12.25 \mathrm{fg}$ & $12.33 \mathrm{ef}$ & $13.08 \mathrm{bcd}$ & $12.04 \mathrm{~B}$ \\
4 & $11.16 \mathrm{hi}$ & $11.66 \mathrm{gh}$ & $12.91 \mathrm{cde}$ & $14.91 \mathrm{a}$ & $12.66 \mathrm{~A}$ \\
6 & $11.25 \mathrm{~h}$ & $12.75 \mathrm{cdef}$ & $13.33 \mathrm{bc}$ & $13.58 \mathrm{~b}$ & $12.72 \mathrm{~A}$ \\
Means & $10.72 \mathrm{D}$ & $11.81 \mathrm{C}$ & $12.79 \mathrm{~B}$ & $13.56 \mathrm{~A}$ & \\
\end{tabular}

Means with different letterings are considerably different in same column and row at $\mathrm{p} \leq 0.05$ LSD.

Upper and lower cases are demonstrating analysis by factorial and single factor respectively.

Number of branches per plant is an essential physiological character in eggplant, as it will contribute to the number of leaves and flowers. Furthermore, reports of this experiment showed significant effects of both chitosan and salicylic acid on increasing the plant size by increasing the number of branches per plant. Application of chitosan is well known in increasing the photosynthesis rate; contribute to improving overall plant growth and improvement (Akter et al., 2018). The finding of current study is consistent with the results of Akter et al. (2018) who observed the effects of chitosan in increasing the number of branches in chillis. Furthermore, Kazemi (2014) reported the significant impact of salicylic acid in increasing the number of branches in tomato plants. Salicylic acid also influences other endogenous Phytohormones such as cytokinins which are able to induce the activities associated to plant growth and development (Krantev et al., 2008). Cytokinins regulate the development of auxiliary buds and increase the number of branches in plants (Qiu et al., 2019; Schneider et al., 2019).

\section{Number of flowers per plant}

In this study, the number of flowers reached from 70.72 (in untreated plants) to 101.8 by foliar application of $\mathrm{CH}$ and SA (Table 4). The finding of this study showed that there was an interaction between different concentrations of $\mathrm{CH}$ and $\mathrm{SA}$ on flower production in eggplant. Untreated plants produced 70.72 flowers per plant only. Meanwhile, all the treated plants produced higher number of flowers, except for $2 \mathrm{ml} / \mathrm{L} \mathrm{CH}$ which was only around 72.08 flowers. Plants treated with $50 \mathrm{mg} / \mathrm{L} \mathrm{SA}+6 \mathrm{ml} / \mathrm{L} \mathrm{CH}, 100 \mathrm{mg} / \mathrm{L} \mathrm{SA}+6 \mathrm{ml} / \mathrm{L}$ and the combination of 150 $\mathrm{mg} / \mathrm{L} \mathrm{SA}+$ all concentrations of $\mathrm{CH}$ produced more than 90 flowers per plant. Plants treated with $150 \mathrm{mg} / \mathrm{L} \mathrm{SA}$ $+4 \mathrm{ml} / \mathrm{L} \mathrm{CH}$ showed superior effect than the others, where the plants in this treatment produced 101.8 flowers per plant. 
Table 4: Effects of chitosan and salicylic acid on total number of flowers plant ${ }^{-1}$

Total number of flowers plant ${ }^{-1}$

\begin{tabular}{clllll} 
& \multicolumn{5}{c}{ Salicylic acid, SA (mg/L) } \\
\cline { 2 - 5 } Chitosan, CH (m1/L) & 0 & 50 & 100 & 150 & Means \\
\hline 0 & 70.721 & $73.97 \mathrm{jk}$ & $78.66 \mathrm{i}$ & $79.5 \mathrm{i}$ & $75.71 \mathrm{D}$ \\
2 & $72.08 \mathrm{k}$ & $81.91 \mathrm{gh}$ & $84.97 \mathrm{f}$ & $96.19 \mathrm{bc}$ & $83.79 \mathrm{C}$ \\
4 & $74.41 \mathrm{jk}$ & $82.44 \mathrm{~g}$ & $89.11 \mathrm{e}$ & $101.8 \mathrm{a}$ & $86.94 \mathrm{~B}$ \\
6 & $74.75 \mathrm{j}$ & $92.66 \mathrm{~d}$ & $95.58 \mathrm{c}$ & $98.55 \mathrm{~b}$ & $90.38 \mathrm{~A}$ \\
Means & $72.99 \mathrm{D}$ & $82.75 \mathrm{C}$ & $87.08 \mathrm{~B}$ & $94.01 \mathrm{~A}$ &
\end{tabular}

Means with different letterings are considerably different in same column and row at $\mathrm{p} \leq 0.05$ LSD. Upper and lower cases are demonstrating analysis by factorial and single factor respectively.

This finding is consistent with the results reported by Afsana et al. (2017) that salicylic acid considerably increased the number of flowers in tomato. Similarly, Mondal et al. (2016) reported that foliar application of chitosan caused a significant increase in reproductive growth of summer tomato. The positive impacts of chitosan on growth and flower production in plants may be due to its potential to perform as anti-transpirant, to activate reactive oxygen species (ROS) scavenging system, to improve the stomatal movement and to motivate growth of xylem vessels (El-Amerany et al., 2020). A part from that, effectiveness of salicylic acid in increasing the flower initiation may be due to the growth-promoting effects linked to changes in the hormonal situation such as cytokinins (Abreu and Munné-Bosch, 2009; Shakirova, 2007).

\section{Conclusion}

It can be concluded that the plant growth regulators showed positive impact in all studied parameters. Due to its cost effectiveness and high number of flowers produced in $4 \mathrm{ml} / \mathrm{L} \mathrm{CH}$ combined with $150 \mathrm{mg} / \mathrm{L} \mathrm{SA}$. In this regard, it suggested that this treatment is included in the cultural practices of eggplants in open field and soil culture.

\section{Conflict of interest}

The authors declare no conflict of interest related to this paper.

\section{Acknowledgement}

The authors acknowledge Universiti Putra Malaysia for providing opportunity and financial support to complete this study. 


\section{Hossaini et al.}

\section{References}

Abbasi, F., Khaleghi, A. and Khadivi, A. The Effect of Salicylic Acid on Physiological and Morphological Traits of Cucumber (Cucumis sativus L. Cv. Dream). Gesunde Pflanzen 72, 155-162 (2020). DOI10.1007/s10343-019-00496-0

Abreu, M. E., and Munné-Bosch, S. (2009). Salicylic acid deficiency in NahG transgenic lines and sid2 mutants increases seed yield in the annual plant Arabidopsis thaliana. Journal of experimental botany, 60(4), 1261-1271. DOI 10.1093/jxb/ern363

Afsana, N., Islam, M. M., Hossain, M. E., Nizam, R., Monalesa, N., Hussain, M. A., and Parvin, S. (2017). Response of Tomato (Solanum lycopersicum L.) to Salicylic Acid and Calcium. Journal of Applied Life Sciences International, 1-7. DOI 10.9734/JALSI/2017/37408.

Akter, J., Jannat, R., Hossain, M., Uddin, J., and Rubayet, T. (2018). Chitosan for Plant Growth Promotion and Disease Suppression against Anthracnose in Chili. International Journal of Environment, Agriculture and Biotechnology (IJEAB), 3(3), 806-817. DOI 10.22161/ijeab/3.3.13.

Amanullah, M. M., Sekar, S., and Vincent, S. (2010). Plant growth substances in crop production: a review. Asian Journal of Plant Sciences, 9(4), 215-222. DOI 10.3923/ajps.2010.215.222

Aranaz, I., Mengibar, M., Harris, R., Panos, I., Miralles, B., Acosta, N., Galed, G., \& Heras, A. (2009). Functional Characterization of Chitin and Chitosan. Current Chemical Biology, 3(2), 203-230. DOI $10.2174 / 2212796810903020203$

Ashraf, M. H. P. J. C., and Harris, P. J. (2013). Photosynthesis under stressful environments: an overview. Photosynthetica, 51(2), 163-190. DOI 10.1007/s11099-013-0021-6.

Aziz, M. A., Esyanti, R., Meitha, K., Dwivany, F., and Chotimah, H. n.d. (2020), Chitosan suppresses the expression level of WRKY17 on red chili (Capsicum annuum) plant under drought stress. DOI10.22146/ijbiotech.55016.

Basudan, N. (2018). Phytochemical composition, of Solanum melongena, Solanum melongena L. and its correlation with bioactive compounds. Research Journal of Pharmaceutical, Biological and Chemical Sciences, 9(4), 479. https://www.rjpbcs.com/pdf/2018_9(4)/[60].pdf.

Mariano-Nasser, D.C.F. A., Borges, C. V., Ramos, J. A., Nasser, M. D., Lundgren, G. A., Furlaneto, K. A. Vieites, R. L. (2019). Bioactive compounds and enzymatic activity in minimally processed eggplant packed 
underactive modified atmosphere. Semina: Ciencias Agrarias, 40(1), 139-148. DOI 10.5433/16790359.2019v40n1p139.

Dempsey, D.A., Klessig, D.F. (2017). How does the multifaceted plant hormone salicylic acid combat disease in plants and are similar mechanisms utilized in humans? BMC Biol 15, 23.

DOI 10.1186/s12915-017-0364-8.

Docimo, T., Francese,G., Ruggiero,A., Batelli,G.,De Palma,M., Bassolino, L., (2016). Phenylpropanoids accumulation in eggplant fruit: characterization of biosynthetic genes and regulation by a MYB transcription factor. Front. Plant Sci. 6:1233. DOI 10.3389/fpls.2015.01233.

El-Amerany, F., Rhazi, M., Wahbi, S., Taourirte, M., and Meddich, A. (2020). The effect of chitosan, arbuscular mycorrhizal fungi, and compost applied individually or in combination on growth, nutrient uptake, and stem anatomy of tomato. Scientia Horticulturae, 261, 109015. DOI10.1016/j.scienta.2019.109015.

El-Mageed, T. A., Semida, W. M., Mohamed, G. F., and Rady, M. M. (2016). Combined effect of foliar-applied salicylic acid and deficit irrigation on physiological-anatomical responses, and yield of squash plants under saline soil. South African Journal of Botany, 106, 8-16. DOI 10.1016/j.sajb.2016.05.005.

El-Miniawy, S. M., Ragab, M. E., Youssef, S. M., and Metwally, A. A. (2013). Response of strawberry plants to foliar spraying of chitosan. Res. J. Agric. Biol. Sci, 9(6), 366-372. http://www.aensiweb.net/AENSIWEB/rjabs/rjabs/2013/366-372.pdf.

El-Yazeid, A. A. (2011). Effect of foliar application of salicylic acid and chelated zinc on growth and productivity of sweet pepper (Capsicum annuum L.) under autumn planting. Research journal of agriculture and biological sciences, 7(6), 423-433. https://www.researchgate.net/publication/273121142.

Esyanti, R. R., Dwivany, F. M., Mahani, S., Nugrahapraja, H., and Meitha, K. (2019). Foliar application of chitosan enhances growth and modulates expression of defense genes in chilli pepper ('Capsicum annuum'L.). Australian Journal of Crop Science, 13(1), 55. DOI: 10.21475/ajcs.19.13.01.p1169.

FAO. 2018. The statistical database (FAOSTAT). Website http://www.fao.org/faostat/en/. [Accessed 21 August 2020]. 


\section{Hossaini et al.}

Gisbert, C., Dumm, J. M., Prohens, J., Vilanova, S., and Stommel, J. R. (2016). A spontaneous eggplant (Solanum melongena L.) color mutant conditions anthocyanin-free fruit pigmentation. HortScience, 51(7), 793798. DOI 10.21273/HORTSCI.51.7.793

Hasanuzzaman, M., Bhuyan, M. H. M. B., Nahar, K., Hossain, M. S., Al Mahmud, J., Hossen, M. S., Masud, A. A. C., Moumita, \& Fujita, M. (2018). Potassium: A vital regulator of plant responses and tolerance to abiotic stresses. Agronomy, 8(3). 31. DOI 10.3390/agronomy8030031.

Ibraheim, S. K. A., and Mohsen, A. A. M. (2015). Effect of Chitosan and Nitrogen Rates on Growth and Productivity of Summer Squash Plants. Middle East Journal of Agriculture Research Research, 04(04), 673-681. https://www.semanticscholar.org/paper/Effect-of-Chitosan-and-Nitrogen-Rates-on-Growthand-Ibraheim-Mohsen/7af2d2537300ef67a5e3f86ca1079ec809ba9ec9.

Jayakannan, M., Bose, J., Babourina, O., Rengel, Z., and Shabala, S. (2015). Salicylic acid in plant salinity stress signaling and tolerance. Plant Growth Regulation, 76(1), 25-40. DOI 10.1007/s10725-015-0028-z.

Kazemi, M. (2014). Foliar Application of Salicylic Acid and Methyl Jasmonate on Yield, Yield Components and Chemical Properties of Tomato. Jordan Journal of Agricultural Sciences, 10(4). https://journals.ju.edu.jo/JJAS/article/view/7777.

Khan, M.I., M. Fatma, T.S. Per, N.A. Anjum, and N.A. Khan. (2015). Salicylic -induced abiotic stress tolerance and underlying mechanisms in plants. Front. Plant Sci. 6:1-17. DOI 10.3389/fpls.2015.00462.

Krantev, A., Yordanova, R., Janda, T., Szalai, G., and Popova, L. (2008). Treatment with salicylic acid decreases the effect of cadmium on photosynthesis in maize plants. Journal of plant physiology, 165(9), 920-931. DOI 10.1016/j.jplph.2006.11.014.

Metwally, A., Youssef, S., El-Miniawy, S. M., and Ragab, M. E. (2013). Effect of foliar spraying of salicylic acid on growth, yield and quality of cold stored strawberry plants. J. Biol. Chem. Environ. Sci., Vol. 8, pp. 1-17. http://research.asu.edu.eg/handle/123456789/1976. 
Mohamed, R.A., Abdelbaset, A.k., Abd-Elkader, D.Y. (2017). Salicylic acid effects on growth, yield and fruit quality of strawberry cultivars. Journal of Medicinally Active Plants, 6(2), 111.https://scholarworks.umass.edu/cgi/viewcontent.cgi?article=1120\&context=jmap.

Mondal, M. M. A., Puteh, A. B., and Dafader, N. C. (2016). Foliar application of chitosan improved morpho-physiological attributes and yield in summer tomato (Solanum lycopersicum). Pakistan Journal of Agricultural Sciences, 53(2), 339-344. DOI 10.21162/PAKJAS/16.2011.

Mondal, M. M. A., Malek, M. A., Puteh, A. B., Ismail, M. R., and Ashrafuzzaman, M. (2012). Effect of foliar application of chitosan on growth and yield in okra. Australian Journal of Crop Science, 6(5), 918-921. https://www.researchgate.net/publication/260347226.

Nada, M. M., \& El-Hady, A. (2019). Influence of Salicylic Acid on Cucumber Plants under Different Irrigation Levels. Journal of Plant Production, 10(2), 165-171. DOI 10.21608/jpp.2019.36246.

Page A.M.L., Daunay M.C., Aubriot X., Chapman M.A. (2019). Domestication of Eggplants: A Phenotypic and Genomic Insight. In: Chapman M. (eds) The eggplant Genome. Compendium of Plant Genome. Springer, Cham. DOI 10.1007/978-3-319-99208-2_12.

Pandey, R. (2015) Mineral Nutrition of Plants. In: Bahadur B., Venkat Rajam M., Sahijram L., Krishnamurthy K. (eds) Plant Biology and Biotechnology. Springer, New Delhi. DOI 10.1007/978-81-322-2286-6_20.

Plazas, M., Prohens, J., Cuñat, A. N., Vilanova, S., Gramazio, P., Herraiz, F. J., et al. (2014). Reducing capacity, chlorogenic acid content and biological activity in a collection of scarlet (Solanum aethiopicum) and gboma (S. macrocarpon) eggplants. Int. J. Mol. Sci. 15, 17221-17241. DOI $10.3390 /$ ijms 151017221

Qiu, Y., Guan, S. C., Wen, C., Li, P., Gao, Z., and Chen, X. (2019). Auxin and cytokinin coordinate the dormancy and outgrowth of axillary bud in strawberry runner. BMC plant biology, 19(1), 528. DOI 10.1186/s12870-019-2151-X. 


\section{Hossaini et al.}

Raigón, M. D., Prohens, J., Muñoz-Falcón, J. E., and Nuez, F. (2008). Comparison of eggplant landraces and commercial varieties for fruit content of phenolics, minerals, dry matter and protein. J. Food Comp. Anal. 21, 370-376. DOI 10.1016/j.jfca.2008.03.006

Vicente, R.S.M., and Plasencia, J. (2011). Salicylic acid beyond defence: its role in plant growth and development. Journal of experimental botany, 62(10), 3321-3338. DOI 10.1093/jxb/err031

Sahu, G. K. (2013). Salicylic acid: Role in plant physiology and stress tolerance. In Molecular, stress physiology of plants (pp. 217-239). Springer, India. DOI 10.1007/978-81-322-0807-5_9.

Schneider, A., Godin, C., Boudon, F., Demotes-Mainard, S., Sakr, S., and Bertheloot, J. (2019). Light regulation of axillary bud outgrowth along plant axes: an overview of the roles of sugars and hormones. Frontiers in plant science, 10, 1296. DOI 10.3389/fpls.2019.01296

Shakirova F.M. (2007) Role of Hormonal System in the Manifestation of Growth Promoting and Antistress Action of Salicylic Acid. In: Hayat S., Ahmad A. (eds) Salicylic Acid: A Plant Hormone. Springer, Dordrecht. DOI 10.1007/1-4020-5184-0_4

Souri, M.K., and Tohidloo, G. (2019). Effectiveness of different methods of salicylic acid application on growth characteristics of tomato seedlings under salinity. Chemical and Biological Technologies in Agriculture, 6. 26. DOI 10.1186/s40538-019-0169-9.

Ullio, L. (2003) Eggplant Growing. Agfact H 8.1.29. third edition. Available at: www. Agric, Nsw. Gov. Au. http://www.dpi.nsw.gov.au/_data/assets/pdf_file/0004/126292/Eggplant-Growing-AgfactH8.1.29.pdf.

Xu, C., and Mou, B. (2018). Chitosan as soil amendment affects lettuce growth, phytochemical efficiency and gas exchange. HortTechnology, 28(4), 476-480. DOI 10.21273/HORTTECH04032-18

Youssef, R. A., El-Azab, M. E., Mahdy, H. A., Essa, E. M., and Mohammed, K. A. (2017). Effect of salicylic acid on growth, yield, nutritional status and physiological properties of sunflower plant under salinity stress. International Journal of Pharmaceutical and Phyto pharmacological Research, 7(5), 5458.https://eijppr.com/en/article/effect-of-salicylic-acid-on-growth-yield-nutritional-status-andphysiological-properties-of-sunflower-plant-under-salinity-stress. 